\title{
A ESCOLA NA REDE: APRESENTAÇÕES DA ESCOLA NO CIBERESPAÇO
}

\author{
Larissa Fabricio Zanin ${ }^{1}$ \\ Moema Martins Rebouças ${ }^{2}$ \\ Universidade Federal do Espírito Santo
}

\section{RESUMO}

A pesquisa apresenta reflexões sobre os modos de apresentação da vida escolar a partir da figuratividade apresentada e nos discursos verbais dos adolescentes nas comunidades virtuais das redes sociais digitais, mais especificamente o Orkut. Discute também o modo como a escola se apresenta em seu site oficial e quais as relações e dilemas que se estabelecem entre o visual que a escola constrói de si e o visual construído pelos adolescentes, sujeitos que constituem seu espaço físico. Tomando como referencial teórico os estudos referentes a análise do discurso que permeiam a Semiótica Discursiva dentre outras reflexões pertinentes a sóciossemiótica, pudemos compreender de que modo os alunos, por meio das comunidade virtuais, apresentam a escola de um modo que em muito difere do modo como a escola se apresenta em seu site oficial.

Palavras-chave: Escola, Modos de Apresentação, Ciberespaço.

\section{ABSTRACT}

The research presents reflections on modes of presentation of school's life from figuration presented by teens verbal discourses in virtual communities of social networks, specifically Orkut. It also discusses how the school presents itself on its website and which relationships and dilemmas are established between the self-built school's view and the adolescents view, individuals who constitute their physical space.Taking as theoretical studies concerning the analysis of discourse that permeate the discourse of semiotics among other relevant considerations to sociosemiotics, we understand how students, through the virtual community, presents the school in a way that differs greatly from the way the school has on its official website.

Keywords: School, Presentation Modes, Cyberspace.

\footnotetext{
${ }^{1}$ Professora de Fotografia no Departamento de Artes Visuais

${ }^{2}$ Doutorado em Comunicação e Semiótica pela PUC/SP e Pós- Doutoramento pela Faculdade de Belas Artes da Universidade do Porto.
} 


\section{INTRODUÇÃO}

O desenvolvimento da tecnologia da informação abriu caminhos para grandes mudanças sociais e culturais, novas possibilidades de criação e socialização, estabelecendo novas relações entre tempo e espaço, dando origem ao contexto que hoje denominamos Cibercultura. Tendo seu lugar no ciberespaço, onde se vive em aceleração sem sair do lugar, permitem deslocamentos, histórias, espaços, tempos e identidades virtuais. "É virtual toda entidade "desterritorializada", capaz de gerar diversas manifestações concretas em diferentes momentos e locais determinados, sem contudo estar ela mesma presa a um lugar ou tempo particular." (Levy, p.47)

Dentre a extensa rede de relações existentes nesta virtualidade específica do ciberespaço, interessa-nos as chamadas "Comunidades Virtuais", criadas com o intuito de reunir pessoas, possibilitando novos modos de sociabilidade. Muitas delas são espaços exclusivos para veicular imagens fotográficas como o Flirck e os mais variados formatos de Blogs. Somados aos sites dedicados a publicação única e exclusiva de fotografias encontram-se uma gama de sites de relacionamentos que possibilitam dentre os mais variados modos de socializar-se a participação nas chamadas comunidades virtuais.

O ciberespaço proporciona assim novos modos de ser e estar na sociedade, sendo lugar de desterritorizalizações e reterritorializações Nesse sentido podemos afirmar que a medida que são criadas comunidades do ciberespaço que re-significam territórios fixos pré-existentes estamos falando de desterritorializações.

De acordo com Lemos (2005), "criar um território é se apropriar, material e simbolicamente, das dimensões da vida". Desse modo, toda territorialização seria um modo de significar territórios e toda desterritorialização seria a re-significação de determinado território.Nesse sentido, podemos afirmar que, à medida que são criadas comunidades do ciberespaço que ressignificam territórios fixos preexistentes, estamos falando de desterritorializações.

O termo desterritorialização, comumente utilizado para definir as dinâmicas do ciberespaço, tem suas raízes na proposição de Gilles Deleuze e Felix Guattari em Mil Platôs: Capitalismo e esquizofrenia (v. 3), no qual propõem três teoremas para pensar os processos de desterritorializações. Em muitos casos, principalmente no "ORKUT" encontramos espaços virtuais que localizam espaços territorializados, são as chamadas comunidades. Determinada por uma página na web, dentro dos domínios do site de relacionamento Orkut, encontramos espaços virtuais que simulam bairros, escolas, igrejas, 
cidades, etc, sob o nome de comunidade. As comunidades virtuais do Orkut convidam as pessoas a simular na rede a sua presença em determinados espaços ou grupos sociais, através da participação nas comunidades virtuais.

A extensa rede de relações existentes na virtualidade do Orkut desencadeou o interesse de investigar como a escola é apresentada na rede social Orkut por meio das chamadas "Comunidades Virtuais" e como ela se apresenta em seu site institucional. Após a análise dos dois modos de apresentação e de visibilidade da escola, apresentaremos ao final um quadro comparativo de como o Colégio Salesiano Nossa Senhora da Vitória é visto pela comunidade e como ele quer ser visto em seu site institucional.

Dentre as possibilidades de interação possíveis nas comunidades do Orkut e no site institucional do Colégio Salesiano Nossa Senhora da Vitória pretendemos analisar os vídeos como meio de aprendizagem verificando, a partir de suas especificidades, como se dão os regimes de interação e sentido proposto por Eric Landowski.

Landowski apresenta um escopo teórico para pensar os modos como um sujeito constrói suas relações com o mundo, com o outro e com ele mesmo. Ao identificar as relações entre os actantes da enunciação Landowski propõe quatro regimes de interação que dialogam entre si. Os regimes de interação correspondem aos modos de agir dos actantes, a partir de dois modos de presença no mundo: o fazer ser e o fazer fazer, sendo os primeiros inerentes ao regime da programação e do acidente e o último, da manipulação e do ajustamento.

O regime da programação é fundamentado na regularidade de comportamentos dos atores, que podem ser dados tanto por causas físicas como por condições sócioculturais. Neste regime o actante tem um papel temático predeterminado nas narrativas, ou seja, está associado às regularidades simbólicas, onde as formas de ação entre sujeitos ou entre sujeito e objeto acontecem em interobjetividade e exterioridade.

Outro regime proposto por Landowski é o do acidente. Segundo o autor este regime contrapõe-se a programação, pois está diretamente relacionado à ruptura das regularidades, dos papéis temático predeterminados. O regime do acidente é fundamentado no risco e está relacionado ao surpreendente, à descontinuidade dos comportamentos pré-determinados.

Já o regime da manipulação acontece em termos de intersubjetividade e interioridade, ou seja, está fundado sobre o princípio da intencionalidade. A manipulação requer um sujeito capaz de avaliar valores postos a prova e um manipulador que faça com 
que este sujeito faça as suas escolhas. São procedimentos persuasivos no qual um sujeito age sobre o outro o conduzindo a um querer/dever algo ou alguma coisa e esse sujeito é conduzido a fazer fazer. Por esse motivo a manipulação depende de dois sujeitos: um que deseja que o outro deseje. A manipulação depende então de um contrato entre os sujeitos e segundo Landowski (2009) a lógica da manipulação nos remete a uma problemática que é "econômica".

Ao contrário da Manipulação, o quarto regime, o do ajustamento é baseado na lógica do contato, na qual um sujeito busca fazer junto e sentir junto. O sentido está na relação entre os actantes e nas transformações que neles se operam tão somente por sua co-presença sensível (Landowski, 2009). Se na manipulação a interação está fundada sobre o fazer crer, o ajustamento passa por um fazer sentir, que é a ordem do contágio cuja característica principal é o ser sentido. Trata-se de uma transformação que se dá por meio do ajustamento de um sujeito ao outro. Esse fazer junto implica na adaptação de um ao outro. $O$ actante com o qual se pretende interagir não tem um comportamento previsível.

Em "Intecciones Arriesgadas" Landowski afirma também que os regimes não são independentes um do outro, e que em uma mesma situação podemos encontrar os quatro regimes de interação, passando de um para o outro e até mesmo coexistindo entre si.

Dentre os mais diversos sites de relacionamentos existentes, selecionamos o ORKUT e o Site Institucional do Colégio Salesiano Nossa Senhora da Vitória, como locus desta pesquisa, com o objetivo de compreender como a escola é apresentada pelos usuários desta rede social na própria rede e como a escola se apresenta institucionalmente em seu site.

Dentre a gama de possibilidade de relações presentes nessa comunidade virtual, nos interessa as Comunidades Virtuais como modo de socialização, mais especificamente a Comunidade "Salesiano de Vitória - ES". As "Comunidades" do Orkut são criadas com o intuito de reunir pessoas, possibilitando novos modos de sociabilidade. Em muitos casos, principalmente no "Orkut", encontramos espaços virtuais que localizam espaços territorializados, são as chamadas "comunidades". 


\section{A ESCOLA NA REDE}

Determinada por uma página na web dentro dos domínios do site de relacionamento Orkut, encontramos espaços virtuais que simulam bairros, escolas, igrejas, cidades, etc. As comunidades virtuais do Orkut convidam as pessoas a simular na rede a sua presença em determinados espaços ou grupos sociais, através da participação delas nesse "novo" espaço. Ao criar um perfil no Orkut, o usuário pode relacionar as comunidades das quais deseja fazer parte e até mesmo criar uma nova comunidade. Logo na primeira página da rede de relacionamentos Orkut aparecem em destaque, na parte inferior direita da página, as comunidades das quais aquele usuário faz parte.

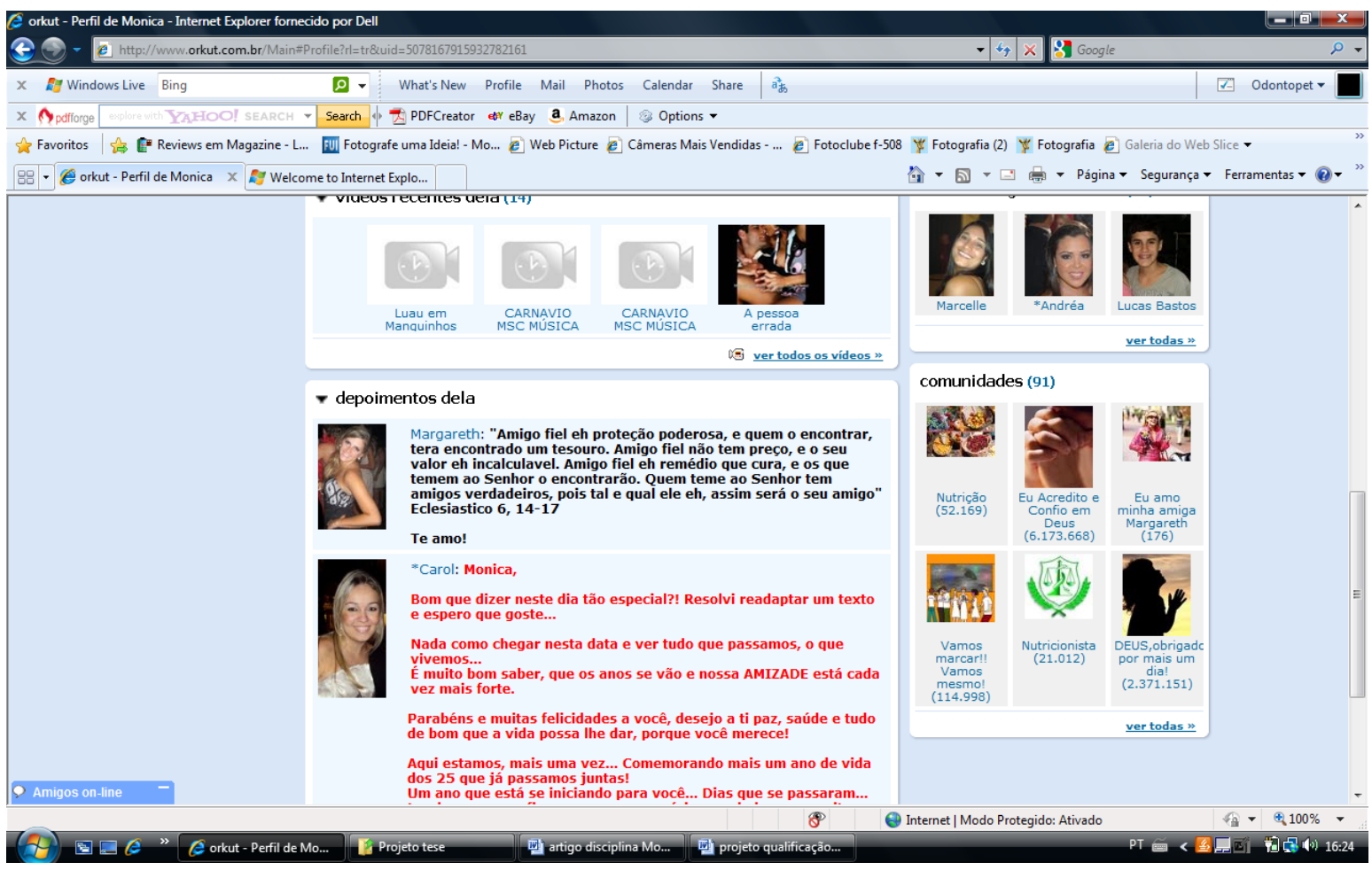

Imagem 1: Detalhe da página inicial do Orkut

As comunidades podem ser constituídas por pessoas com um interesse em comum em determinado assunto ou área, ou podem ser representações virtuais de espaços físicos dos quais os participantes façam parte e/ou se incluam neles.

Interessa-nos aqui compreender os modos de relações possíveis nas comunidades virtuais do Orkut, que propõem um simulacro de uma comunidade física, territorializada, mais especificamente as presentes na comunidade "Salesiano de Vitória ES”, que compreende um espaço virtual que representa o espaço físico do Colégio 
Salesiano Nossa Senhora da Vitória, localizado na Avenida Vitória, na cidade de Vitória, ES. Este tipo de prática vem sendo cada vez mais utilizada por estudantes, proporcionando alargamentos e deslocamentos das relações de espaço e tempo das salas de aulas, produzindo novas relações espaço-temporais que muitas vezes não são vivenciadas no espaço físico institucionalizado da escola.

A comunidade "Salesiano de Vitória - ES" foi criada em 23 de junho de 2004 pela usuária Bianca Menezes, uma ex-aluna do Colégio Salesiano Nossa Senhora da Vitória. Em conversa com a direção da escola obtivemos a informação de que a comunidade foi criada sem a autorização da instituição e que eles não são responsáveis pelos conteúdos presentes na página.

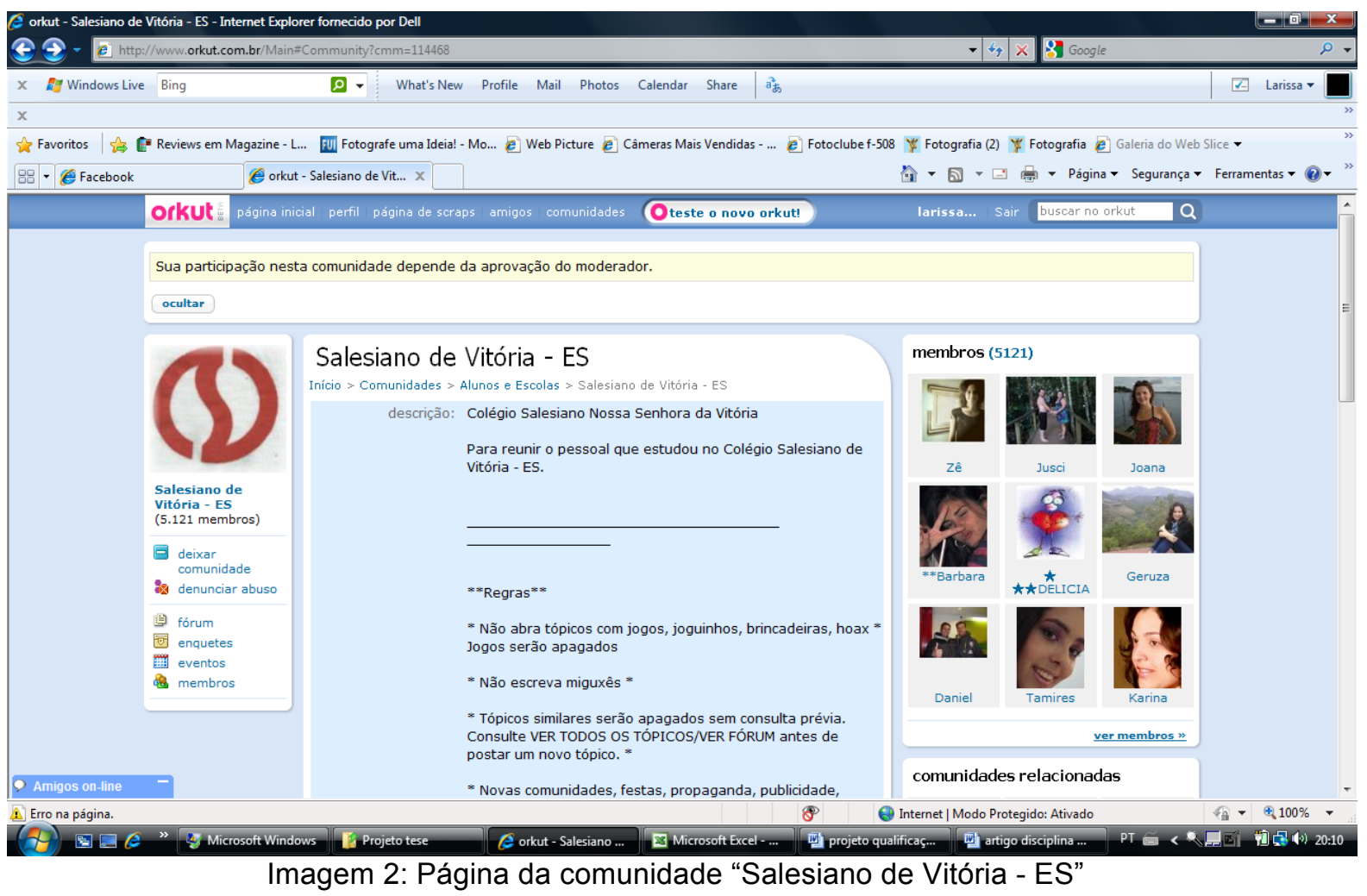

Logo na primeira página da comunidade, na descrição de seu conteúdo, vemos na referência ao espaço físico do Colégio, o próprio nome "Colégio Salesiano Nossa Senhora da Vitória", deixando claro logo no primeiro acesso da página virtual, que aquele espaço é um simulacro do Colégio Salesiano; e a seguir a comunidade define seu objetivo: "Para reunir o pessoal que estudou no Colégio Salesiano Nossa Senhora da Vitória".

Percebemos então a primeira marca de um processo de desterritorialização do espaço físico do Colégio Salesiano Nossa Senhora da Vitória e sua reterritorialização por 
meio da criação da Comunidade Virtual "Salesiano de Vitória - ES". Na cidade de Vitória existem duas unidades do Colégio Salesiano, uma no bairro Forte São João e outra no bairro Jardim Camburi. A comunidade que estamos analisando refere-se ao espaço físico localizado no Forte São João.

Após definir para quem a comunidade é destinada, são relacionadas as regras que devem ser respeitadas neste espaço virtual. Mesmo sendo um espaço virtual, reiterase a presença de "regras" de comportamento, assim como é comum nas escolas de ensino tradicional, entre as quais o Colégio Salesiano está (ela é uma escola confessional, o que a torna ainda mais exigente quanto ao cumprimento das regras). Desse modo, apresentase então na comunidade uma representação do comportamento exigido pela escola e vivenciado pelos ex-estudantes, membros da comunidade, funcionando assim como um espaço virtual da escola, programado e estruturado por regularidades.

O que figurativiza a identidade da comunidade é a logomarca da rede salesiana em destaque no canto direito da página, reiterando a ideia de que é um simulacro do espaço físico, ou seja a reterritorialização, que também tem como marca uma placa, com a logomarca da escola.

A comunidade conta com 5.121 membros participantes, todos eles estão identificados no canto superior direito da página. Logo abaixo dos membros, encontramos as comunidades relacionadas à Comunidade Salesiano de Vitória - ES. Entre elas, comunidades que reúnem ex-alunos que simpatizam como um determinado professor, como a comunidade "Eu tive aula com o Sergião", que conta com 706 membros, e comunidades temporais do Colégio Salesiano, ou seja, comunidades que reúnem exalunos que frequentaram o colégio em um determinado período como, por exemplo, a comunidade "Salesiano anos 80" que conta com 431 membros. 


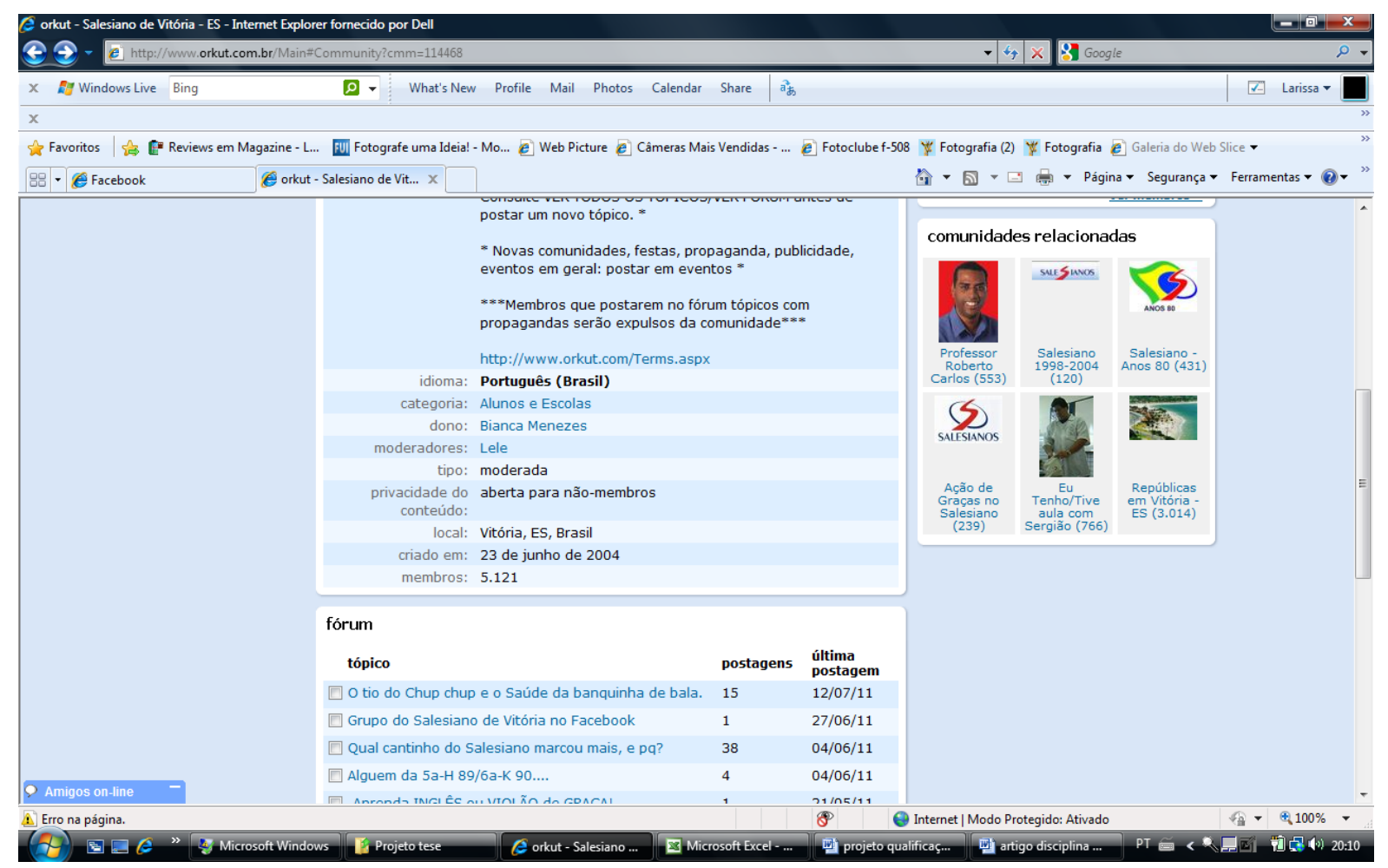

Imagem 3: Detalhe da página da comunidade "Salesiano de Vitória - ES"

A comunidade é definida quanto à "privacidade de conteúdo" como aberta para não-membros, o que significa que para acessar as informações presentes nesta comunidade não é necessário ser participante dela. Nesse sentido, ela se afasta do espaço físico territorializado da instituição, uma vez que no Colégio só podem entrar alunos uniformizados identificados com a carteira estudantil específica da escola ou sujeitos autorizados após triagem na portaria.

A marca das comunidades virtuais do Orkut são os fóruns de discussão, que são abertos por tópicos e nos quais os participantes da comunidade podem interagir. Qualquer um dos participantes da comunidade pode criar um tópico e, aqueles que fizerem parte da comunidade, podem ou não interagir com o comentário postado. Desse modo todos que participam da comunidade podem, por meio de um poder fazer, criar um fórum para discussão sobre determinado assunto e os outros participantes, neste momento enunciatários do fórum proposto, podem ou não, por meio de um querer fazer, deixarem-se manipular e interagir.

Umas das regras da comunidade é que não se pode abrir tópicos de discussão similares a outros já existentes, entretanto, essa regra pode ser burlada pelos participantes 
da comunidade. Para que isso não aconteça o criador enunciador da comunidade, ao definir as regras, manipula os participantes enunciatários a não criarem fóruns com discussões por intimidação com o seguinte discurso: "Tópicos similares serão apagados sem consulta prévia. Consulte VER TODOS OS TÓPICOS/VER FÓRUM antes de postar um novo tópico". Também por meio de uma manipulação por intimidação o criador da comunidade deixa claro que os fóruns são espaços para discussões e nele não devem ser veiculados outros tipos de informação. Com o discurso marcado por certa intolerância informa: "Membros que postarem no fórum tópicos com propagandas serão expulsos da comunidade", mas antes avisa que para isto existe um espaço específico: "Novas comunidades, festas, propagandas, publicidade, eventos em geral: postar em eventos". Assim como o "Fórum", a parte da comunidade denominada "Eventos" também permite que os usuários publiquem quaisquer informações que desejarem.

Desse modo, percebe-se que a comunidade "Salesiano de Vitória - ES" no Orkut reitera em muitos aspectos os comportamentos vividos e exigidos no espaço físico da escola. Com regras e penalidades para quem descumpri-las, assim como na escola, a comunidade tentar ser um espaço das regularidades com relação a sua organização, e para isso impõe sistemas de controle semelhantes, como acompanhamento das participações, penalizações, além de espaços específicos para cada ação. Do mesmo modo que no espaço físico da escola não se pode, por exemplo, comer lanche ou beber suco dentro da biblioteca, uma vez que o espaço apropriado para isso é a cantina e o pátio, na comunidade espaço de discussão não deve ser confundido com espaço de divulgação.

A comunidade virtual "Salesiano de Vitória - ES" conta com mais de 40 tópicos abertos e, dentre eles, resolvemos analisar os tópicos que tiveram a última postagem no ano de 2011, entre os meses de junho e julho. São eles "o tio do Chup chup e o Saúde da banquinha de bala" que conta com 15 interações e "Qual cantinho do Salesiano marcou mais, e pq?" que conta com 38 interações. 


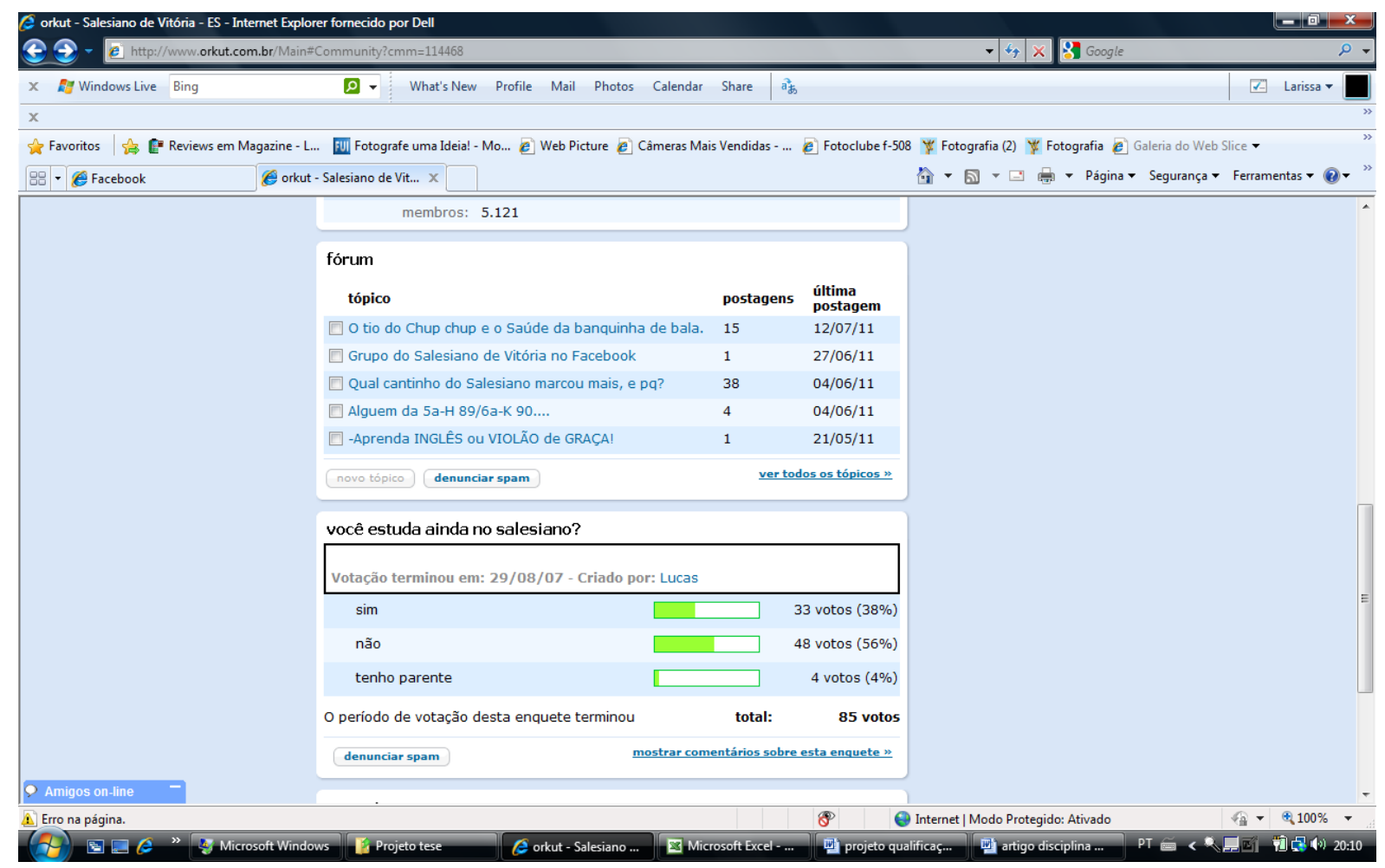

Imagem 4: Detalhe da página da comunidade "Salesiano de Vitória - ES"

O Fórum "O tio do Chup chup e o Saúde da banquinha de bala", foi aberto pela participante da comunidade "Fê", em 10 de maio de 2005, com o seguinte comentário:

"Vocês se lembram deles... então acho que o tio do chup chup deve ter ficado rico as nossas custas... pelo menos eu contribui muito para isso... todo dia era um chup chup de coco.... fala sério e a quantidade de bala que o saúde vendia na banquinha, as top's de linha eram: bala maluquinha,a depois bala de iogurte e logo em seguida aquelas balas redondinhas de canela..... nossa não tinha cartela de passe que desse conta da quantidade de bala e chup chup, nunca tinha passe escolar no final do mês.... hehehe bons tempos...."

Logo após o comentário que abre o fórum, outros 15 comentários surgem, uns ainda no ano de 2005 e o último em 2011. Cada um relata sua experiência pessoal com o vendedor de balas, o "Saúde", e o vendedor de chup chup, o "Tio do Chup Chup". Todos têm lembranças que são físicas e transpostas para o ciberespaço com descrições em detalhes, de modo que podemos criar imaginários de cada situação. 


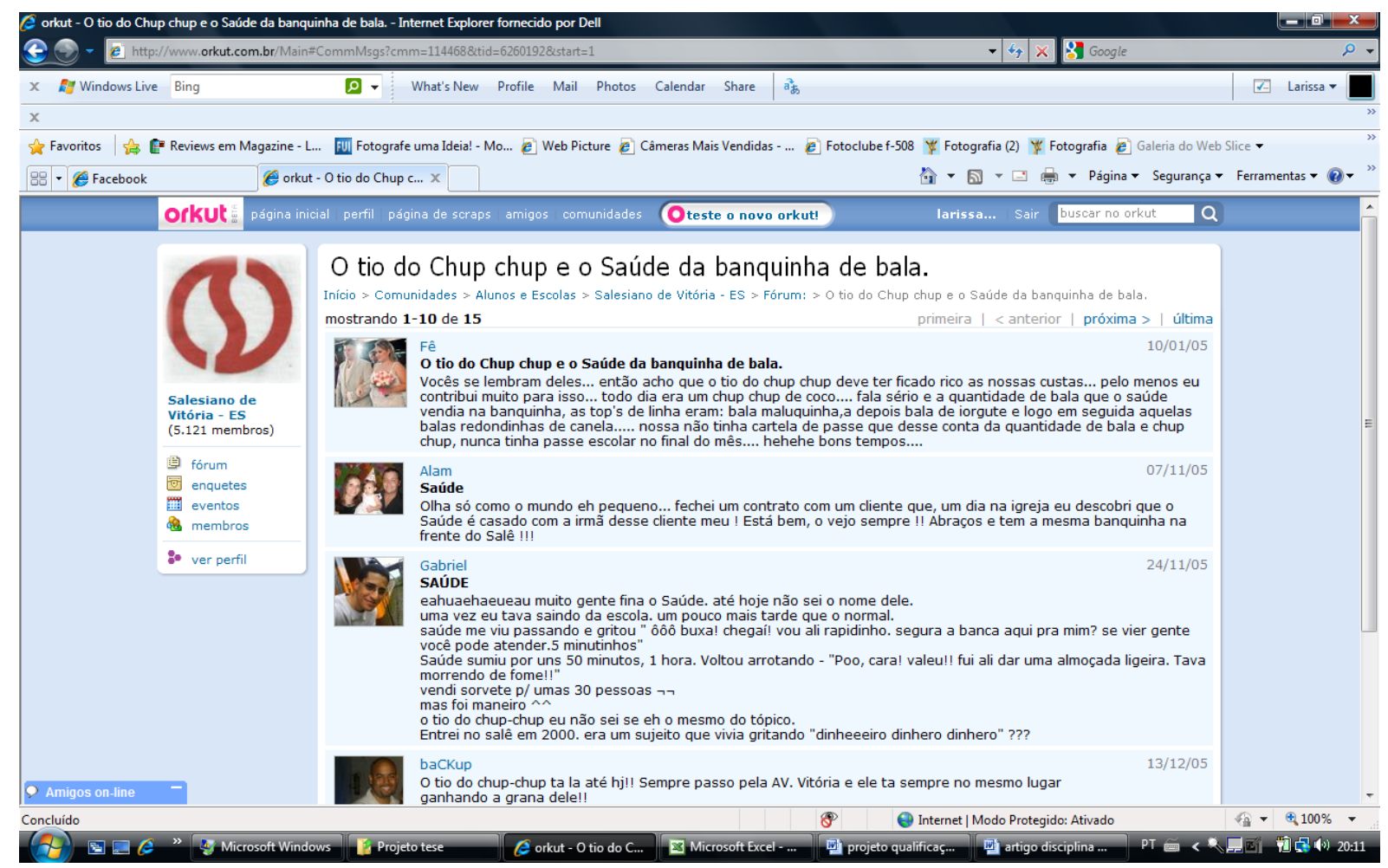

Imagem 5: Detalhe da página da comunidade "Salesiano de Vitória - ES"

O "Saúde" e o "Tio do Chup Chup" não são funcionários do Colégio Salesiano e não têm nenhuma ligação direta com a escola. Entretanto, são reconhecidos como presenças na rotina da escola e na vida dos alunos por meio dos produtos que vendem, as balas e o chup chup. Esses produtos são elementos atravessadores que fazem com que algo que pertence somente ao ambiente externo, ou seja, ao público, adentre o ambiente interno privado da escola, a ponto da presença desses elementos imporem criações de regras no cotidiano da escola, como: a proibição de comer balas ou mascar chiclete dentro da sala de aula. A escola é movida o tempo todo por ações de controle que tentam manter o espaço privado "blindado" de tudo aquilo que não foi imposto por ela dentro dela, "os muros demarcam claramente a passagem entre as duas realidades: o mundo da rua e o mundo da escola, como que a tentar separar algo que insiste em se aproximar. A escola tenta se fechar em seu próprio mundo, com suas regras, ritmos e tempos" (DAYRELL, 1996, p. 147)".

Os deveres impostos na escola concebem a existência modal dos sujeitos ao determinar a existência modal dos objetos, as balas e chup-chup são objetos modais da liberdade, os alunos sabem quais são os limites (físicos e reguladores) impostos pela 
escola, e, mesmo assim, ou justo por ser assim, sabem, podem e querem ser (sujeitos movidos pelo desejo), e pelo poder-fazer (liberdade).

Desse modo, a bala e o chup-chup e a relação estabelecida com quem os vende figurativizam modos de ser e de comportamento de quem quer interagir com eles (os alunos), e quem quer ter o controle dessa interação (como os propositores das regras da escola). O compra dos doces constituem-se como práticas sociais cotidianas dos alunos da escola, fazendo com que esta seja movida por um desejo de poder consumir algo que é não permitido pela instância controladora (a escola) e tentar, diariamente, burlar as regras que são impostas.

Esta relação é estabelecida entre os alunos e os doces, objetos de autonomia e de liberdade, uma vez que comprar ou não é um escolha do aluno e não uma decisão da instituição. A compra do doce, além de constituir uma prática social, cria vínculos afetivos entre os alunos que compram e os vendedores, proporcionam, por meio dos vínculos afetivos estabelecidos, o ajustamento entre estes sujeitos.

A presença constante desses sujeitos no cotidiano do colégio é reiterada nas interações do fórum. Todos que participam deste fórum afirmam que os dois são sujeitos participantes da rotina da escola e todos os que postam um tópico relatam uma experiência pessoal com algum deles. Temos então, no fórum, um segundo momento de ajustamento, agora entre os alunos e ex-alunos que revivem esta memória. A primeira chamada convida os participantes da comunidade a interagir e aqueles que se sentem ajustados participam, relatando suas experiências pessoais com os vendedores de doce.

Alguns tópicos reiteram o que disse a usuária "Fê" e outros contam que encontraram um ou outro em situações da vida profissional, o que marca o distanciamento físico atual com os vendedores de bala e de chup chup, outros, ainda, falam de suas preferências de sabores com certo saudosismo.

\footnotetext{
"Olha só como o mundo eh pequeno... fechei um contrato com um cliente que, um dia na igreja eu descobri que o Saúde é casado com a irmã desse cliente meu ! Está bem, o vejo sempre !! Abraços e tem a mesma banquinha na frente do Salê !!!" (Alam em 07/11/2005)

"O Saúde era massa, mas o tio do chupchup era o melhor! Ele conhecia todo mundo pelo nome e os pais, aí a gente fica esperando as vezes o pai ir buscar e quando pai chegava ele já gritava "fulano seu pai chegou". Ele era o maximo!" (Larissa em 27/02/2010)
}

A última postagem traz notícias recentes dos dois sujeitos e a surpresa de seu enunciador ao saber que os dois fazem parte da rotina do Salesiano há tanto tempo, além de informar que o Saúde não é mais o dono da banquinha de balas: 


\begin{abstract}
"Caramba! eu sabia que o tiozinho do chup-chup tava la a muito tempo ,mas não sabia que era tantooo tempo.O Saúde vendeu a banquinha agora ta um cara chaaaato,prefiria tio saúde.O tiozinho do chup-chup é muito doidoooooo,ele fica gritando :"BORA GALERA,BORA GALERA,QUERO IR EMBORAAA".ELE É MUITO LEGAL !!!" (Ana Luiza, em 12/07/2011).
\end{abstract}

Percebemos na postagem da última usuária a acessar este fórum a relação de proximidade entre o vendedor "Saúde", o "Tio do Chup Chup" e os alunos da escola, reiterada em outras interações.

Além de serem denominados de "Tios" pelos participantes da comunidade, o que Ihes dá aparentemente uma proximidade quase familiar, todos aparentam gostar do fato de que estes sujeitos conhecem os alunos pelo nome, e muitas vezes os pais dos alunos, fazendo parte da rotina da escola e da vida pessoal deles: mesmo que suas bancas fiquem na parte externa do colégio, eles aparecem dentro da comunidade, e em muitas interações chegamos a pensar que eles ficavam dentro da escola.

Percebemos que todos os comentários, de certo modo, reiteram e sancionam positivamente o primeiro tópico aberto pela usuária "Fê", construindo pela discursividade a presença e a aproximação estabelecida entre os vendedores e os alunos de maneira eufórica. Desse modo, a substituição do "Saúde" na banquinha de bala foi recebida de maneira disfórica por uma usuária: "O saúde vendeu a banquinha agora ta um cara chaaaato, prefiria tio saúde".

O regime de interação que se estabelece na comunidade "Salesiano de Vitória ES" é o do ajustamento, no qual a todo momento o sentido construído é dado pela copresença sensível. Os sujeitos são instigados a participar do fórum a partir do disparador proposto pela usuária "Fê", que parte de uma chamada sensível, levando os participantes da comunidade a um fazer sentir, por meio do contágio. Essa presença contagiosa é marcada aqui pelo sentimento, pelo saudosismo que todos sentem da presença desses dois sujeitos em suas vidas.

Um segundo fórum foi aberto com uma pergunta "Qual Cantinho do Salesiano mais marcou, e pq?", foi postado pelo participante "Danilo", em oito de julho de 2004, com o seguinte comentário:

"Hum... eu acho que essa pergunta vai render coisa. Mas eu não esqueço o balcão do guarda-volume da biblioteca, onde trabalhei durante toda a $7^{\mathrm{a}}$ série. Foi lá que fiz muitas das amizades que tenho hoje, e tb foi um cantinho de paqueras, de estudos e de leitura. Eu li todos os livros da Stella Carr enquanto estava lá! Sem dúvida foi uma boa época!" 


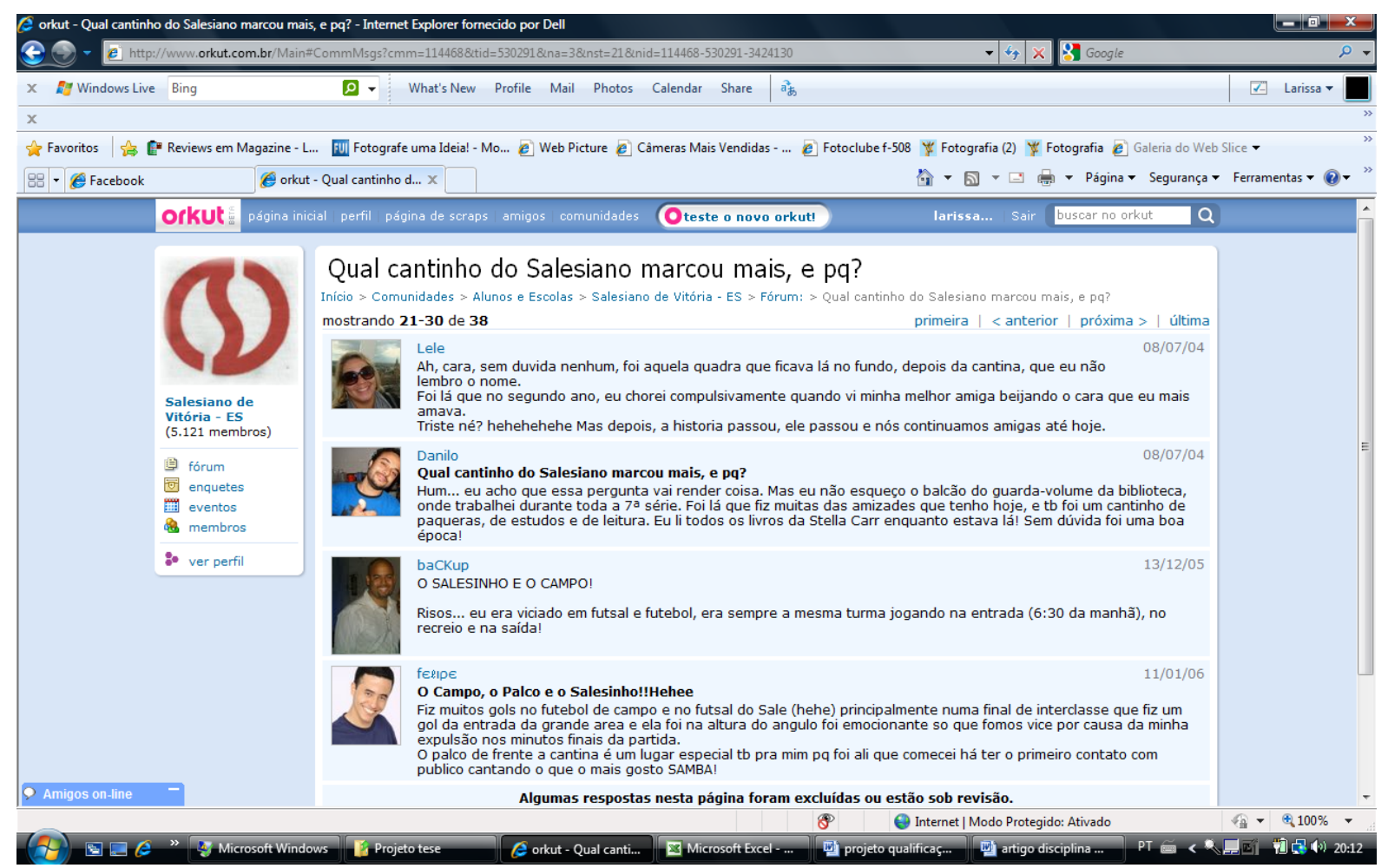

Imagem 6: Detalhe da página da comunidade "Salesiano de Vitória - ES"

Este tópico nos convida a fazer um passeio virtual pelos espaços físicos da escola, nesse proceder a comunidade virtual reterritorializa-o em certa fisicialidade, só possível no espaço então desterritorializado. Em alguns momentos somos capazes de fazer plantas imaginárias do colégio, como quando nos comentários os participantes localizam os lugares físicos da escola localizada na Avenida Vitória.

Um bom exemplo é o comentário seguinte, que menciona uma das quadras da escola

"Ah, cara, sem duvida nenhuma, foi aquela quadra que ficava lá no fundo, depois da cantina, que eu não lembro o nome. Foi lá que no segundo ano, eu chorei compulsivamente quando vi minha melhor amiga beijando o cara que eu mais amava. Triste né? hehehehehe Mas depois, a historia passou, ele passou e nós continuamos amigas até hoje." (Lele em 08/07/2004).

A figurativização da quadra é construída pelas categorias da expressão "fundo" e "atrás" que estabelecem uma tipologia que nos remete a um espaço físico que não estamos vendo e vivendo, mas que é significado por meio da linguagem. 


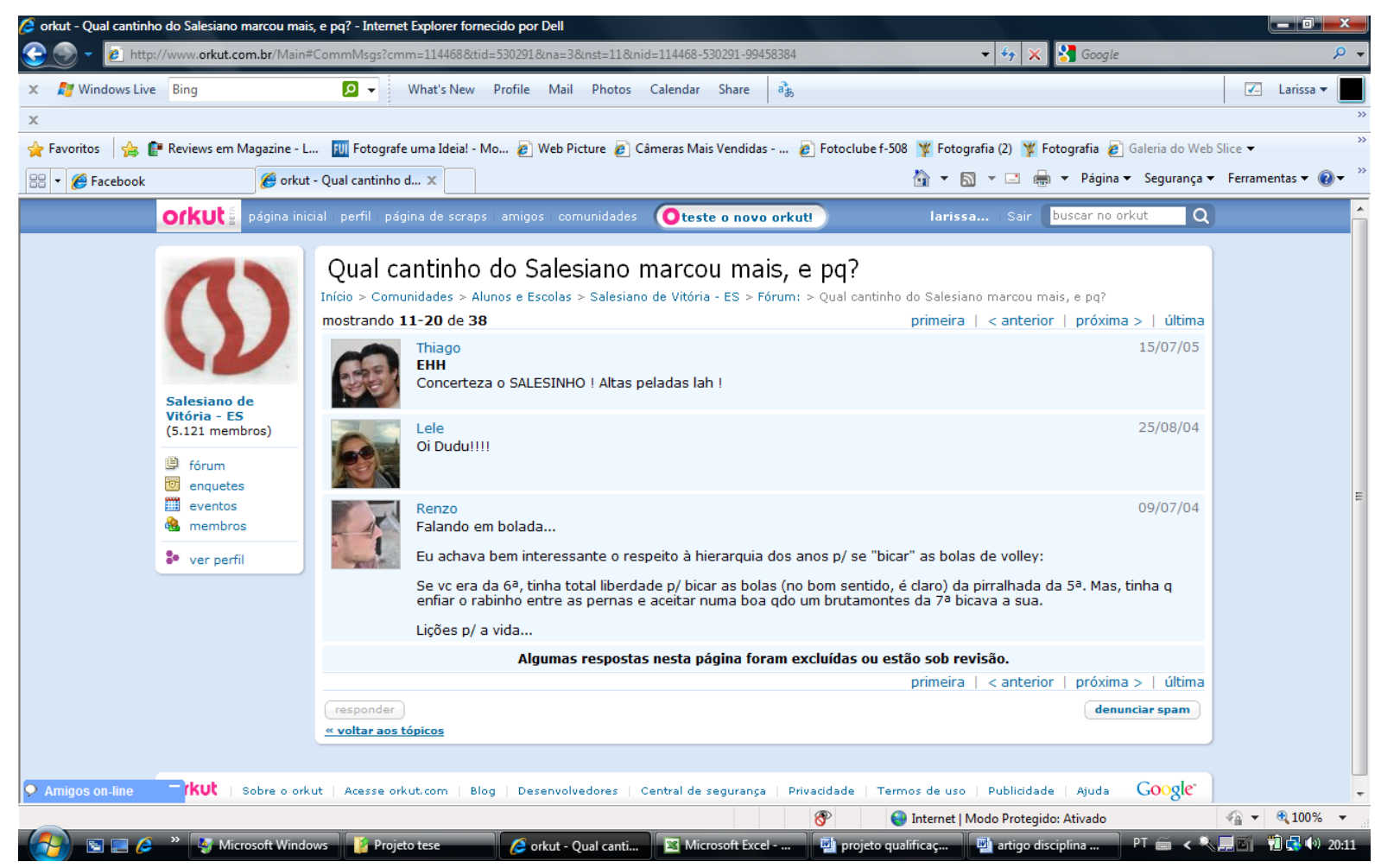

Imagem 7: Detalhe da página da comunidade "Salesiano de Vitória - ES"

A cada comentário temos mais localizações físicas dos espaços da escola. A todo momento os usuários retomam sua relação com o espaço escolar, sempre partindo de uma experiência sensível com o mesmo. Ao ler cada interação somos convidados a traçar uma planta imaginária da escola que nos é dada a ver pelos ex-alunos.

A maior parte dos comentários apresenta como espaço preferido uma das quadras de esporte da escola conhecida por todos que passaram por lá como "Salesinho". Por ser uma quadra coberta é nela onde acontecem os eventos culturais da escola, como Festa Junina, Ação de Graças, Jogos Interclasses, encerramento do ano letivo, entre outros. Esta quadra configura-se como um espaço significante de uma prática social.

Outros destacam o espaço em frente à cantina, que denominam de "palco". Neste espaço os alunos costumam organizar apresentações musicais durante o recreio, como descreve o participante da comunidade "Felipe Mocidade":

"O Campo, o Palco e o Salesinho!!Hehee

Fiz muitos gols no futebol de campo e no futsal do Sale (hehe) principalmente numa final de interclasse que fiz um gol da entrada da grande area e ela foi na altura do angulo foi emocionante so que fomos vice por causa da minha expulsão nos minutos finais da partida. 
O palco de frente a cantina é um lugar especial tb pra mim pq foi ali que comecei há ter o primeiro contato com publico cantando o que o mais gosto SAMBA!"

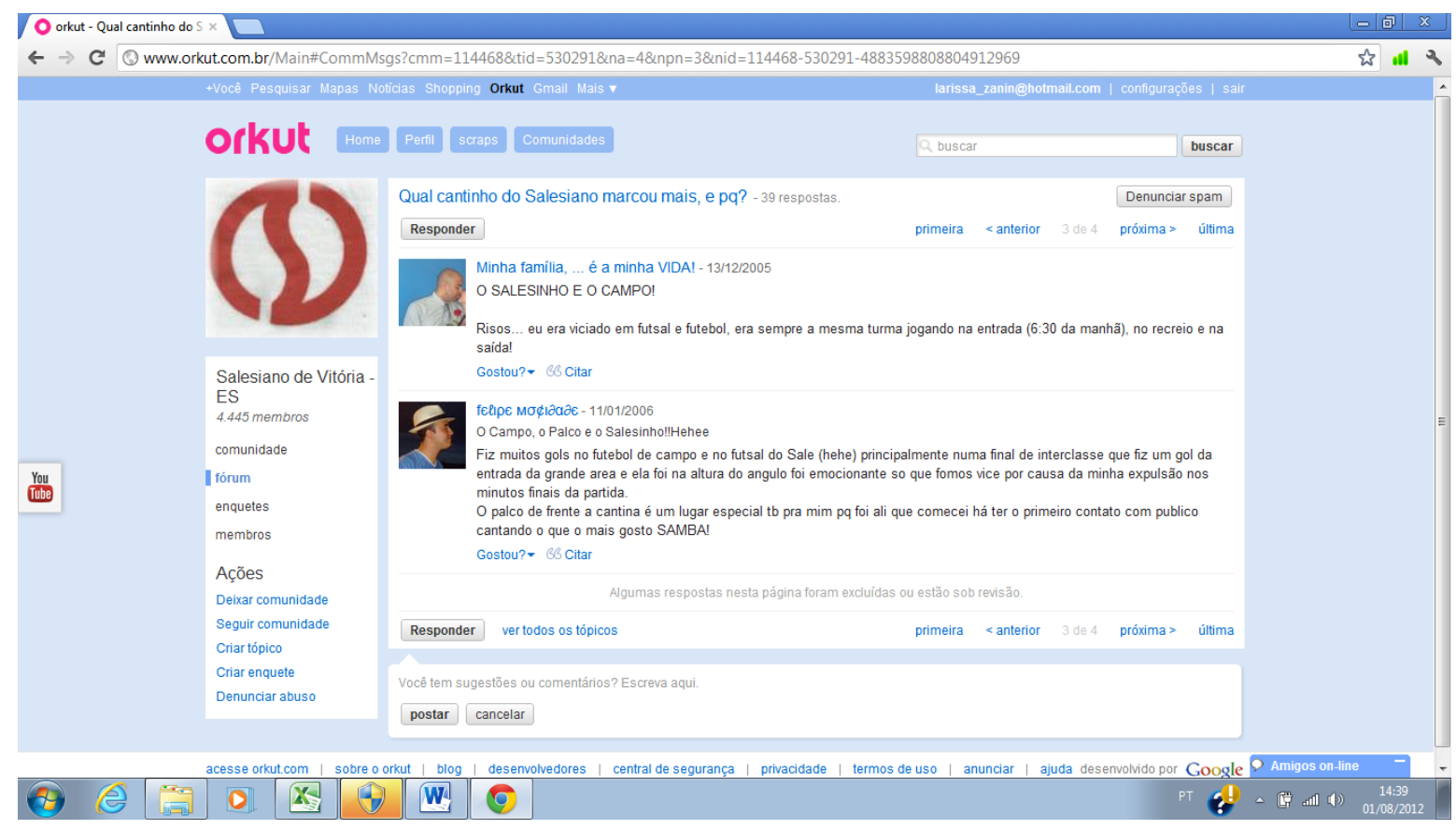

Imagem 8: Detalhe da página da comunidade "Salesiano de Vitória - ES"

Percebemos no Fórum "Qual Cantinho do Salesiano marcou mais, e pq?" a reterritorialização do espaço físico do Colégio Salesiano Nossa Senhora da Vitória por meio das interações verbais. O espaço territorializado localizado na Avenida Vitória passa inicialmente por um processo de desterritorialização ao ser transposto verbalmente nas interações do fórum. Consequentemente cria-se um novo território ressignificado na rede social por meio da linguagem, o que Deleuze denomina reterritorialização do colégio. É nesse processo que percebemos a primeira grande diferença de entendimento do espaço que os alunos e ex-alunos constroem sobre a escola.

Pensada para ser um espaço funcional para atender às demandas e necessidades de uma instituição de ensino cujo valor social é de lugar do saber e, para tanto, ali são inscritos todos os programas do dever e do fazer destinados a este fim, no contexto do território os sujeitos assumem seus papéis temáticos de alunos em busca do objeto valor em questão: o saber.

A arquitetura e ocupação do espaço físico não são neutras. Desde a forma de construção até a localização dos espaços, tudo é delimitado formalmente, segundo princípios racionais, que expressam uma 
expectativa de comportamento de seus usuários. Nesse sentido, a arquitetura escolar interfere na forma da circulação das pessoas, na definição das funções para cada local. (DAYRELL, 1996, p. 147)

Ao serem convidados a transpor o espaço territorializado pela chamada do fórum na comunidade iniciam, os participantes então o processo de desterritorialização e reterritorialização do "Colégio Salesiano". Nesse momento entra-se em um programa do sentir e sob o papel temático de ex-aluno passa-se a experimentar e (re)vivenciar o espaço a partir de uma experiência sensível e, assim, este espaço reterritorializado apresenta-se uma transformação do espaço como significante de um significado social (GREIMAS, 1976, p.118).

Sendo o espaço reterritorializado apresentado na comunidade compreendido como linguagem e manifestado na linguagem espacial ("a quadras coberta atrás da cantida", "o palco em frente à cantina", "a escada embaixo da biblioteca"), faz com que "os objetos que entrarão em relação com os sujeitos reconhecidos neste texto não interessarão enquanto tais, mas somente em virtude de algumas de suas propriedades sensíveis: visuais, sonoras, térmicas, olfativas, etc." (GREIMAS, 1976, p. 125). Desse modo, a memória e os afetos fazem ser estes sujeitos, uma vez que são suas histórias que os constituem como ex-alunos daquele espaço, como pertencentes àqueles territórios, e o (re)encontro e a oportunidade de vivenciar novamente os espaços daquela escola que um dia foi deles proporciona a todos que fizeram parte dela este encontro de sentir junto, por meio de uma comunidade virtual, própria do regime do ajustamento.

Por meio das comunidades virtuais os alunos dão à escola um novo espaço, um lugar no ciberespaço que nem sempre é o lugar que ela desejaria estar, mas que contém as significações que os alunos fazem dela e os sentidos por eles construídos sobre elas: "[...] se apropriam dos espaços que a rigor não thes pertence, recriando nele novos sentidos e suas próprias formas de sociabilidade (DAYRELL, 1996, p. 147)".

A Comunidade "Salesiano de Vitória - Es" nos é apresentada mesclando marcas do próprio espaço físico Colégio Salesiano como a logomarca da instituição que é utilizada como identificação no perfil da comunidade, que se localiza na Avenida Vitória, no município de Vitória, e marcas inerentes ao espaço virtual criado para a escola. Uma destas marcas é o modo de presença neste fórum, que permite que sujeitos pertencentes ou não à comunidade escolar salesiano tenham acesso à comunidade virtual. 
Enquanto na escola as relações extracurriculares, ou seja, os assuntos que não compõem o currículo escolar são tratados nos corredores ou no pátio durante os intervalos, na comunidade virtual estas relações são construídas por meio do fórum. Uma das semelhanças entre esses espaços, que são tão divergentes quanto à presença física, é a temática da conversa que quase sempre pertence à esfera do sensível.

Mesmo que no espaço virtual as escolhas de como a escola será apresentada não sejam uma decisão da instituição, percebemos que os modos como se constitui na virtualidade a "comunidade salesiana" por meio da presença e interações dos sujeitos que fazem parte dela muitas vezes reiteram os modos de presença no espaço físico do Colégio Salesiano da Avenida Vitória. Percebe-se, então, que o ciberespaço é mais um lugar de interação entre os sujeitos que compõem a comunidade escolar, e mais um modo de presença da escola em suas vidas, estabelecendo desse modo novas formas de sociabilidade entre eles.

Ainda na rede "www" encontramos outro espaço virtual que apresenta o Colégio Salesiano Nossa senhora da Vitória: é página institucional da escola, organizada e atualizada pela própria instituição com um caráter predominantemente informativo. A página da escola é atualizada constantemente, trazendo informações importantes sobre a rotina da escola e divulgando os eventos que a escola participou ou organizou.

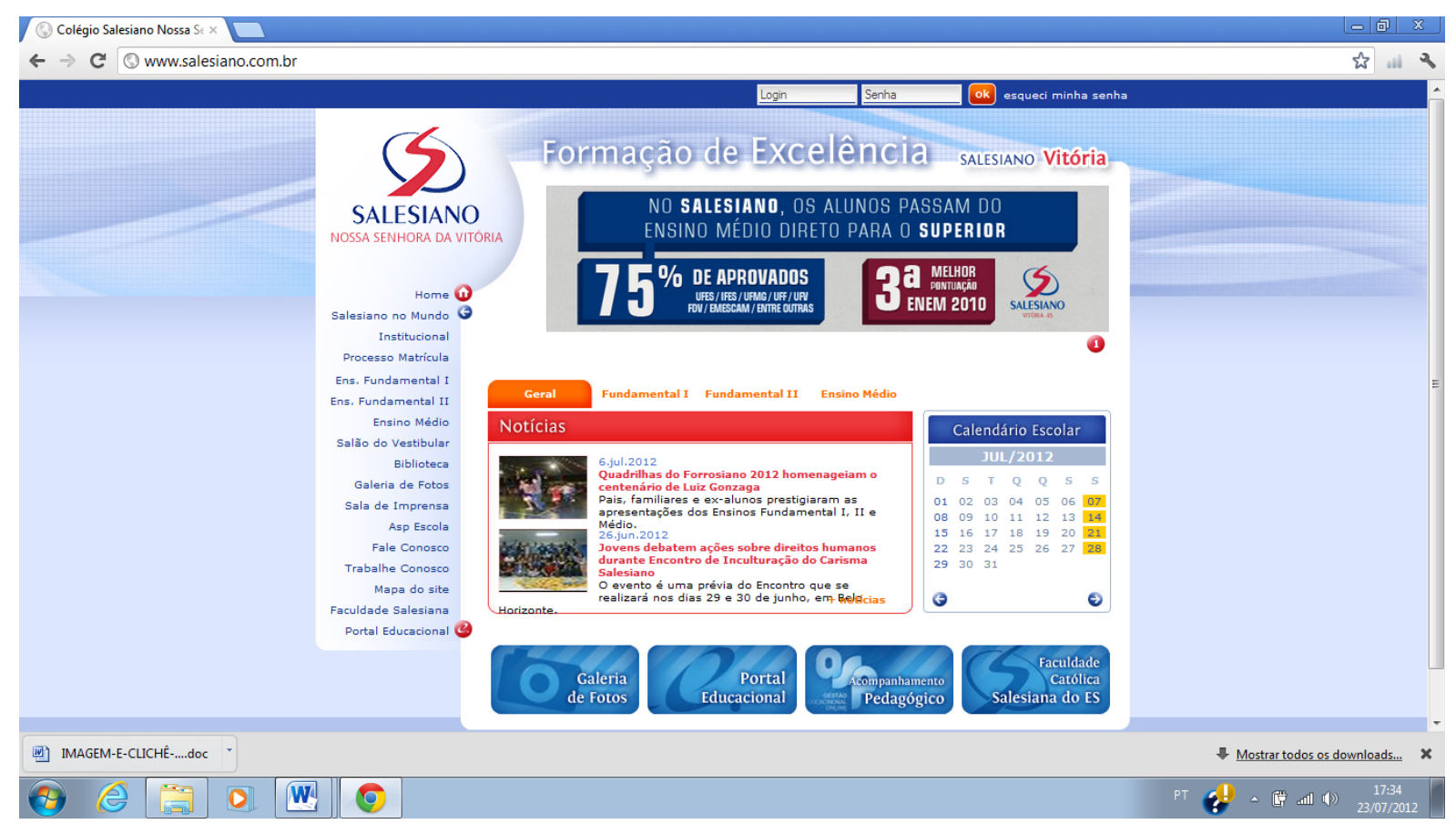

Imagem 9: Site Institucional do Colégio Salesiano Nossa Senhora da Vitória 
O Colégio Salesiano Nossa Senhora da Vitória mantém esta página institucional oficial na internet no endereço www.salesiano.com.br, aberto para todos que tiverem interesse. A layout da página é construído em um fundo azul claro com os links de interesse e as chamadas principais centralizadas sobre este fundo. Do lado esquerdo encontram-se os links que apresentam a escola. Ao selecionar um link abre-se um texto no centro da página, no lugar onde na página principal encontram-se as chamadas e as notícias da escola. O site é construído sob um regime de programação caracterizado pela "ação programada sobre as coisas", ou seja, só se pode ter acesso a determinado conteúdo acessando o link destinado para tal, e para isso o site disponibiliza um link denominado "Mapa do Site", no qual indica os passos que devem ser seguidos para atingir os objetivos desejados.

As chamadas principais ficam localizadas no topo da página e mudam constantemente. No início do ano as chamadas destacam o período de matrículas e convidam o usuário a conhecerem a proposta pedagógica da escola (conforme apresentado na página 47). Na imagem acima a chamada destaca o desempenho da escola no vestibular, dando ênfase aos percentuais de aprovação atingidos por seus alunos. Acima do quadro da chamada principal a frase "Formação por Excelência" é colocada em destaque ao lado do nome do colégio "Salesiano Vitória". Percebe-se que o enunciador Salesiano apresenta em sua página principal um discurso de manipulação por tentação ao apresentar os percentuais de aprovação no vestibular. Os destaques para os números percentuais, a classificação no Enem, além das palavras "Salesiano" e "Superior" em negrito, levam o enunciatário a crer que aqueles que se matriculam e estudam no Salesiano estão mais próximo de alcançarem o ensino superior.

Logo abaixo está o quadro de notícias da escola, no qual são apresentados os acontecimentos de destaque dentro da rotina escolar, como a festa junina da escola e a participação dos alunos no evento institucional denominado "Salê-ONU" que, conforme apresentado no site, é um evento "baseado no Modelo Intercolegial das Nações Unidas (Mini-ONU) da PUC de Minas Gerais", no qual os estudantes puderam vivenciar uma rotina de diplomatas, defendendo a política externa de suas representações em encontros de organizações internacionais". Ao noticiar sua participação neste evento percebe-se a intencionalidade da escola em querer ser vista como uma instituição que se preocupa com uma formação crítica de seus alunos com relação à situação política atual. 
A notícia sobre a festa junina da escola, a chamada "Quadrilhas do Forrosiano", denominação que remete ao nome da instituição, destaca o evento como sendo um momento de confraternização entre escola e família, além de sua importância cultural, já que a temática da festa foi uma homenagem ao centenário de Luiz Gonzaga. O texto apresentado no site destaca

A alegria das festas juninas tomou conta do Colégio Salesiano Nossa Senhora da Vitória no último sábado, dia 30 de junho. Pais, familiares, alunos e ex-alunos prestigiaram mais uma edição do Forrosiano. Para o ano letivo de 2012, as quadrilhas dos Ensinos Fundamental I, II e Médio prestaram uma homenagem ao centenário do Rei do Baião, Luiz Gonzaga.

Além das quadrilhas que fizeram os convidados lotarem a arquibancada do Ginásio Salesinho, todos puderam conhecer um pouco da trajetória de um dos maiores compositores da música brasileira por meio de versos recitados pela assistente pedagógica Mírian Faria. (acesso em 22 de julho de 2012)

Apresentando o evento como um momento cultural, a instituição destaca a homenagem a Luiz Gonzaga e a participação de pais, familiares, alunos e ex-alunos. A presença de ex-alunos em um evento atual da escola dá destaque a uma característica desta instituição, que valoriza a permanência do vínculo com todos que por ela passam, uma espécie de laço fraternal que uma vez estabelecido não se rompe entre aqueles que estudaram no Salesiano. É este o modo como aparentemente a escola quer ser vista pelos usuários do site, sendo estes pais, alunos, ex-alunos, pessoas interessadas em conhecer a instituição, uma vez que estas informações são abertas a todos que acessam o site, uma instituição por onde o alunos não passam, e sim permanecem.

A cada link acessado somos convidados a conhecer um pouco das propostas da escola e também de sua história. Considerada uma instituição tradicional, o site tem um link onde destaca a história da Congregação Salesiana no Brasil e no mundo, cujas atividades iniciaram no século XIX. Apresenta também o início da trajetória com o jovem Dom Bosco, responsável pela formação dos inicialmente "salesianos", um grupo de jovens dedicados à educação formal e religiosa. É neste link que se destaca a tradição da rede salesiana em Vitória que, conforme apresentado no site

[...] se instaura no dia 16 de dezembro de 1942 quando o Pe. Emílio Miotti funda o colégio Salesiano no Parque Moscoso, no Centro da Cidade. As primeiras aulas têm início no dia 31 de janeiro de 1943 e a primeira turma contava com setenta alunos matriculados na primeira série ginasial.O colégio se tornava referência para a comunidade e a demanda por vagas na instituição reforçava a qualidade de ensino do Salesiano que mudou de sede para atender os estudantes que almejavam ingressar na instituição de ensino. No dia 08 de setembro de 
1948 começava a construção a futura sede do colégio no bairro de Forte São João. Na época, um lugar ocupado pelo mangue.A nova sede foi inaugurada em 11 de julho de 1951, na Av. Vitória, e em dez anos de trabalho sério e dedicação o Colégio consolidava a marca Salesiano na comunidade e se tornava o maior colégio do Estado. (acesso em 20/07/2012)

Após conhecer a história da rede de ensino e do Colégio Salesiano em Vitória, o próximo link traz detalhes sobre a organização da instituição, sua proposta pedagógica para Ensino Fundamental e Ensino Médio, sua localização e processo de matrícula e um convite para agendamento de visitas. Os links seguintes destacam o vestibular e a Faculdade Salesiana.

O site também apresenta um link denominado "Galeria de Fotos", que se subdivide em outros quatros links organizados por categorias de fotos: Eventos, Projetos Institucionais, Infraestrutura e Galerias Anteriores. Mesmo com as categorias estabelecidas, o que leva a pessoa que está acessando o site a crer que verá os registros da escola separados por temas, todos os links dão acesso às mesmas fotografias, todas elas relacionadas a eventos culturais e educativos da escola.

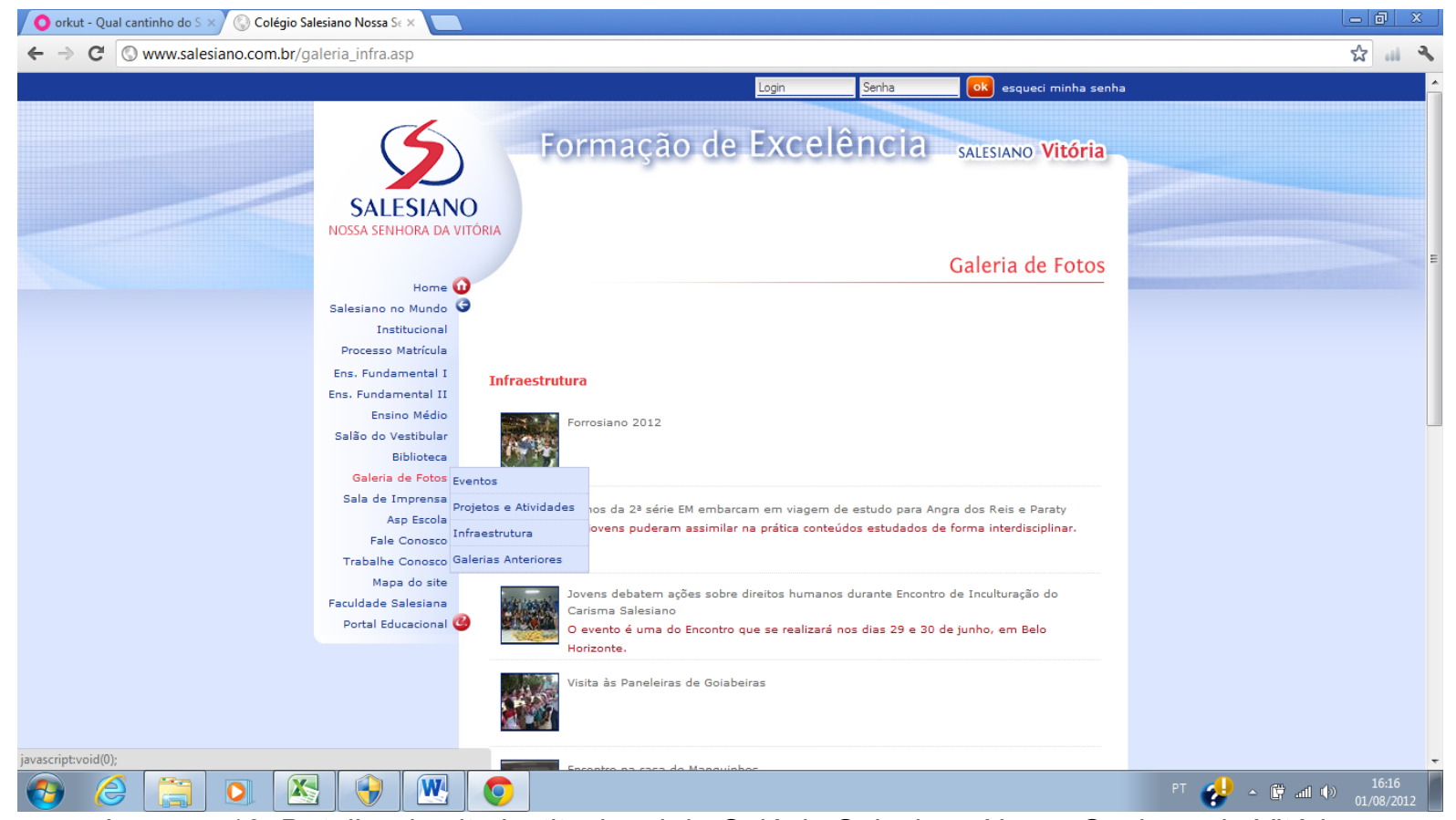

Imagem 10: Detalhe do site institucional do Colégio Salesiano Nossa Senhora da Vitória

O link denominado "APS Escola" (Gestão Educacional On Line)" quebra a característica do acesso público às informações do site, nele somente pais ou responsáveis têm acesso. Pelo "APS" os pais podem acompanhar a rotina escolar de seus filhos com informações sobre avaliações, notas, faltas e ocorrências diversas. É o modo 
que as instituições de ensino encontraram para fazer os pais que não têm tempo de ir pessoalmente à escola participarem da vida escolar de seus filhos. Ao possibilitar aos pais o acompanhamento da vida escolar do filho por instrumento virtual, a escola está, de certo modo, legitimando este distanciamento espacial da família com relação à escola, entretanto este instrumento instaura na família uma falsa sensação de estar lá, criando assim um simulacro de participação.

O sistema "APS" funciona também como um instrumento de controle para os pais, uma vez que, por meio dele, é possível acessar informações sobre o comportamento do aluno, se ele foi advertido, se fez ou não fez a tarefa, se foi retirado de alguma aula por mau comportamento, estabelecendo assim entre a instituição e a família uma espécie de alargamento do controle feito na/pela escola para os pais ou responsáveis. Fica estabelecido assim um contrato fiduciário entre a escola e a família, modalizado por um dever e poder fazer, tanto da escola como dos pais. A responsabilidade da educação dos filhos passa a ser de ambos, e não somente da escola.

O último link também é um acesso privado. O "Portal Educacional" é um espaço dentro do site institucional, onde os alunos podem pesquisar e encontrar informações sobre os conteúdos estudados no momento. Sendo um espaço privado, só têm acesso pais e alunos por meio de um login e uma senha, assim como acontece com o "APS".

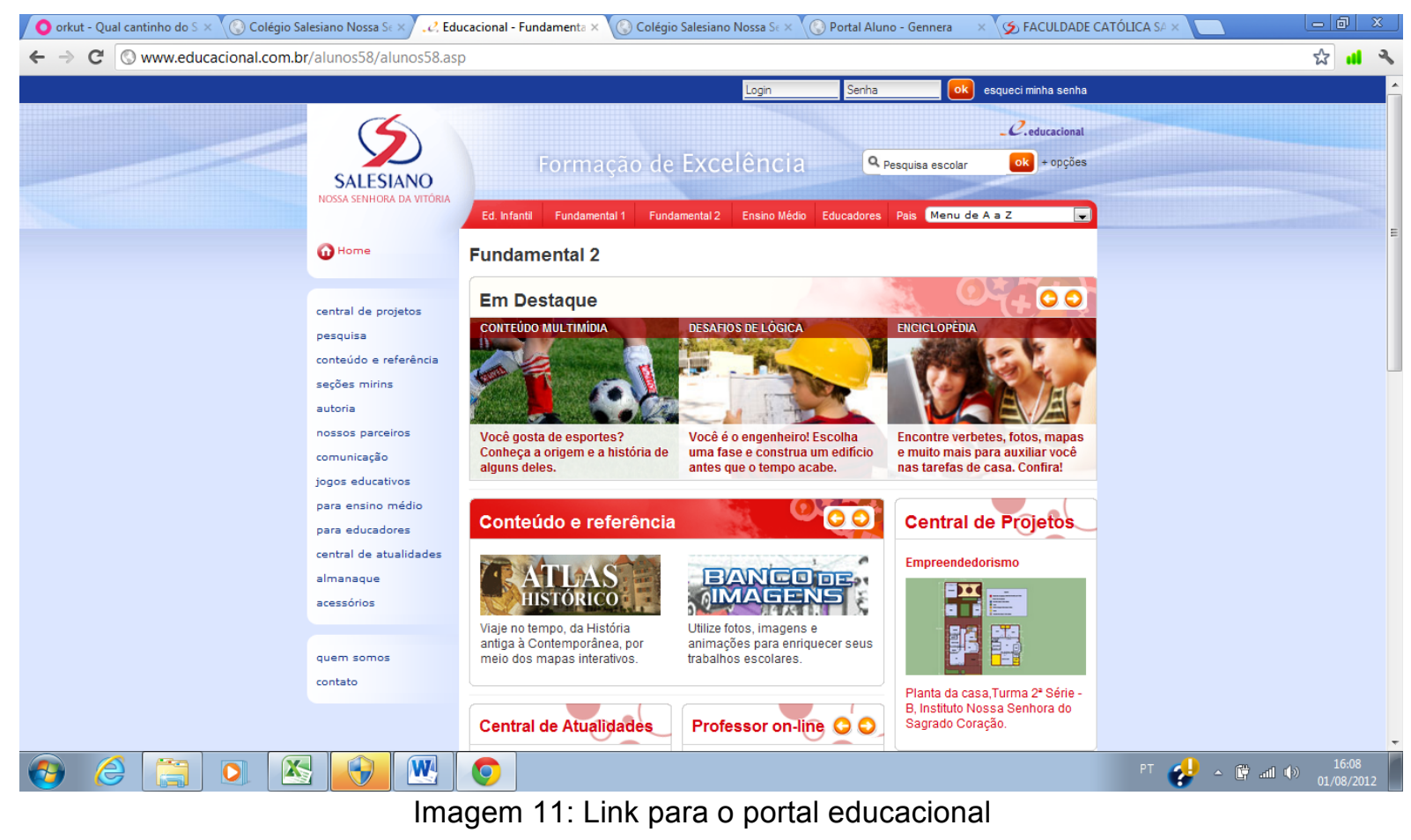




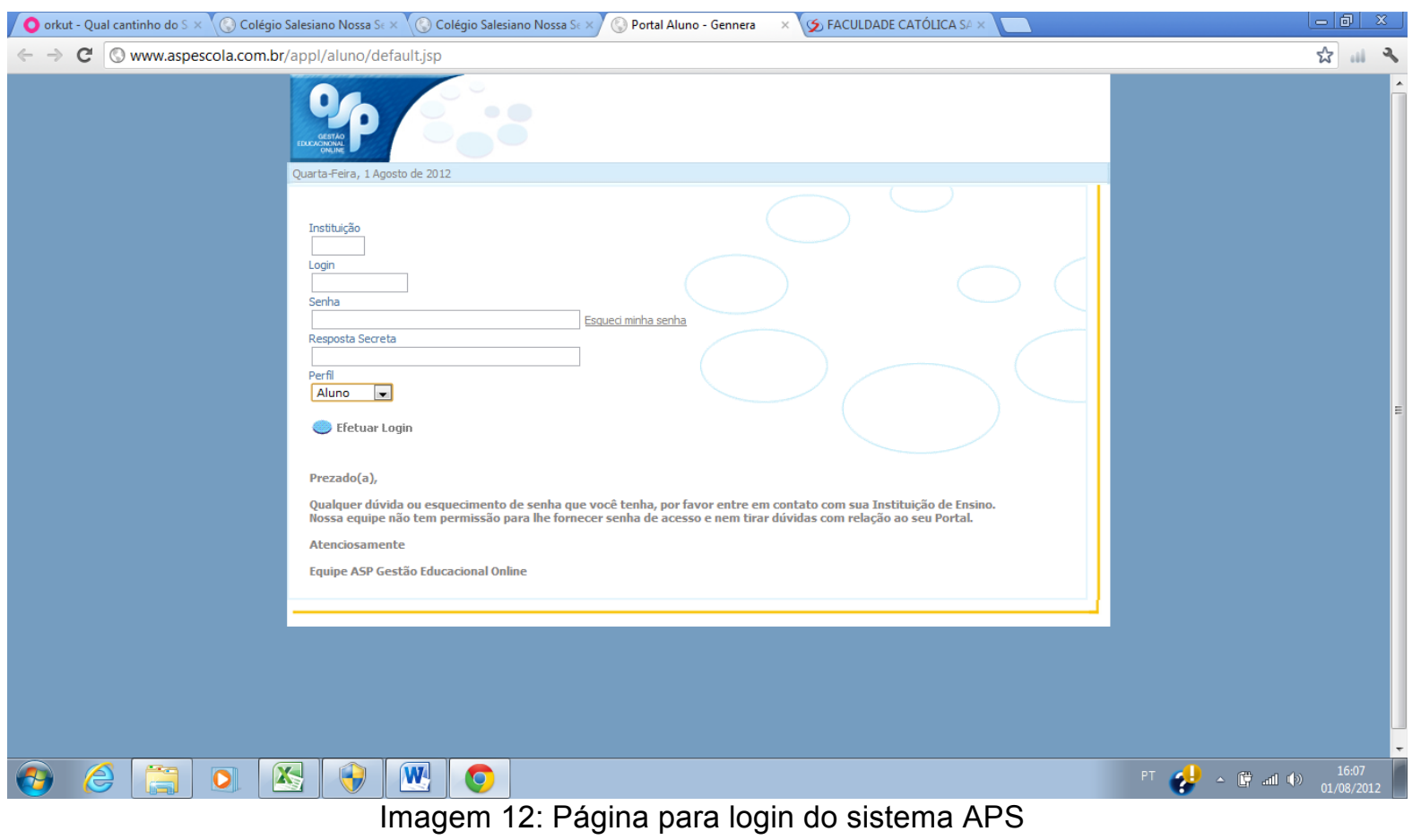

O site institucional reitera em muitos aspectos o espaço físico da escola. Marcado pela ênfase no objeto valor saber e por um querer ser visto como um espaço detentor e atravessador desse saber da escola até ao aluno, é organizado de modo a funcionar dentro do regime da programação com normas e regras, sejam elas da escola em seu espaço físico, sejam ela as de navegação do site.

Assim, o site constitui-se como um espaço fechado onde só é possível acessar aos conteúdos elaborados pela instituição. Por vezes aparenta ser um espaço público, quando se trata do acesso às suas competências apresentadas em seus textos explicativos a cada link, e em alguns momentos privado, quanto os acessos ao "Portal Educacional" e ao "APS" são possíveis somente por meio de login e senha gerados pela própria escola. Já o acesso ao espaço físico da escola é quase sempre privado, permitido somente aos integrantes da instituição. Aos demais a barreira se inicia na portaria do colégio, que autoriza ou não a entrada de pessoas que não pertencem àquela comunidade.

\section{ENTRE TERRITÓRIO E RETERRITORIALIZAÇÃO}

Compreendidos os dois modos de apresentação do Colégio Salesiano na internet, sendo eles a comunidade na rede social Orkut e o site institucional do colégio, interessa- 
nos analisar estes dois modos de apresentação traçando suas oposições, regularidades e irregularidades.

Percebemos que a comunidade "Salesiano de Vitória - ES" é um espaço público e aberto, uma vez que permite que todos o acessem e interajam, alterando-o constantemente quanto ao seu conteúdo, uma vez que o princípio de interação das comunidades é a participação e criação de fóruns, sendo estes permitidos de serem criados por qualquer um de seus membros. O único momento em que a comunidade se constitui como um espaço fechado é no ato de sua criação, onde apenas o usuário que criou pode criar suas regras e alterar suas configurações, mas após a criação todo o movimento gerado nela por seus usuários a configuram como um espaço aberto.

As comunidades permitem interação de seus participantes por meio de fóruns temáticos criados por qualquer usuário pertencente a ela. Os fóruns são criados com uma pergunta ou frase que funcionam como disparadores de discussão, em sua maioria enunciados de estado que levam o enunciatário a um ser-ser. No ato de criação de um fórum o enunciador manipulador lança um disparador, levando outros usuários a participarem com interações. Como não se pode prever como será a interação, podendo ser disfórica ou eufórica com relação ao proposto pelo enunciador do fórum, a comunidade se torna o espaço das irregularidades e das instabilidades, uma vez que lá é o lugar no qual o social se manifesta, e esta manifestação pode ser desde um relato de uma experiência afetiva vivida até uma crítica à própria escola, ou a alguma interação anterior.

$\mathrm{Na}$ comunidade os sujeitos da enunciação, ou seja, os usuários da rede social projetam um discurso que produz um efeito de saudosismo, memória, por meio de um "eu" instaurado em um tempo "então" em um espaço "lá", já que narram uma história de si, mas de um tempo e de um espaço que não são o que vivem agora, marcando o espaço da individualidade e da pessoalidade, no qual cada aluno apresenta a relação pessoal que construiu com aquele espaço, como na postagem do usuário Danilo,

\footnotetext{
"Mas eu não esqueço o balcão do guarda-volume da biblioteca, onde trabalhei durante toda a $7^{\text {a }}$ série. Foi lá que fiz muitas das amizades que tenho hoje, e tb foi um cantinho de paqueras, de estudos e de leitura. Eu li todos os livros da Stella Carr enquanto estava lá! Sem dúvida foi uma boa época!".
}

Ao dizer que não esquece do espaço da biblioteca onde trabalhou por um período apresenta sua relação pessoal com aquele lugar, apresentando suas experiências sensíveis como a paquera, os momentos de leitura e de socialização com os colegas, o que configura a comunidade como o espaço da experiência sensível, marcada pelo regime 
do ajustamento, no qual todos são convidados a interagir e apresentar suas experiências sensíveis com aquele espaço, do qual só participa quem esteve lá, quem sentiu, quem viveu aquela realidade, quem se sente ajustado, configurando a comunidade como um espaço dos ajustes das sensibilidades. Baseado na lógica do contato, na qual um sujeito busca fazer junto e sentir junto, o sentido está na relação entre os actantes e nas transformações que neles se operam tão-somente por sua co-presença sensível (LANDOWSKI, 2009).

As subjetividades são projetadas na maior parte das interações, desde as experiências com o "Saúde" e o "Tio do Chup-Chup" até as relações com o espaço físico da escola, como espaço significante de um significado social, como apresentado pelo participante Felipe, ao falar do palco em frente à cantina: "O palco de frente a cantina é muito especial tb pra mim porque ali comecei a ter o primeiro contato com o público cantando o que mais gosto SAMBA!". Configura-se como espaço do ser-ser e do poderfazer, no qual a marca é a liberdade para expressar a sua experiência pessoal com a escola, sem preocupar-se com as regras e normas do território Colégio Salesiano.

Iniciado um processo de desterritorialização no ato de criação da comunidade, as interações configuram o processo de reterritorialização, no qual o espaço escolar é ressignificado pelos usuários da rede social participantes da comunidade, todos eles exalunos da escola, que fazem daquele espaço um espaço significante de suas experiências sensíveis com a instituição.

Nenhum dos fóruns abertos na comunidade "Salesiano de Vitória - ES" discute as qualidades inteligíveis da escola, como sua proposta pedagógica ou os conteúdos aprendidos, as marcas que ficam para os alunos e ex-alunos são as construídas por suas experiências sensíveis, configurando-a como espaço da afetividade. A noção de aprendizagem que a escola constrói para si não é a mesma construída pelo aluno. Enquanto para aquela a prioridade são os conteúdos das mais variadas disciplinas, para estes a escola é o lugar do encontro, do estabelecimento de relações pessoais, "Fica evidente que essa re-significação do espaço, levada a efeito pelos alunos, expressa sua compreensão da escola e das relações, com ênfase na valorização da dimensão do encontro" (DAYRELL, 1996, p. 147).

Já no site institucional o espaço configura-se ora como público, ora como privado, mas quanto à interação é a todo momento um espaço fechado. O espaço é público no tangente às informações que veicula sobre a instituição, sua rotina escolar, seus pressupostos pedagógicos, sua história, mas configura-se como um espaço fechado 
quanto aos acessos mais intrínsecos da rotina escola, como o acesso a notas, à rotina escolar dos alunos e o acesso às informações do portal educacional, no qual os conteúdos e atividades trabalhados na escola são só permitidos àqueles que pertencem a ela, seja como aluno, seja como pai ou responsável por um aluno.

O sujeito da enunciação é uma instância semiótica, sujeito coletivo, identificado como "Salesiano", instaurando a presença de um "nós" que representa o coletivo que compõe a instituição, que tem como papel social educar, o que configura uma marca de impessoalidade. O discurso projetado marca um tempo de "agora" e um espaço de "aqui", apresentando informações atualizadas da rotina da escola. O site apresenta-se por meio de um simulacro construído por meio das imagens, que veicula como a melhor escola para "seu filho", e, para tanto, você (pai) deve matricular seu filho para proporcioná-lo a melhor educação. Configura-se então o espaço do parecer e do dever-fazer.

Predomina o discurso da objetividade, no qual o que importa é informar a que veio e para que veio. Assim o faz com a notícia principal do mês de julho, a chamada sobre os índices de aprovação no vestibular. Constrói-se mais uma vez o simulacro de melhor escola com a chamada em caixa alta "NO SALESIANO OS ALUNOS PASSAM DO ENSINO MÉDIO DIRETO PARA O SUPERIOR". A chamada configura-se com três enunciados localizados em retângulos, sendo dois azuis e um magenta. No enunciado do primeiro retângulo as palavras "Salesiano" e "superior" aparecem em destaque e o retângulo aparece interligado com o enunciado abaixo, que apresenta o percentual de aprovação. Fica estabelecida então uma manipulação por tentação por parte do enunciador, ou seja, venha para esta escola que você terá aprovação no vestibular. A manipulação é reforçada quando a escola apresenta um terceiro retângulo, com cor diferenciada, com a classificação da escola no Enem (Exame Nacional do Ensino Médio), destacando a classificação e colocando em fonte menor o ano da mesma, 2010.

Estabelece-se então, entre enunciador e enunciatário, um contrato de veridicção por meio dos traços presentes no discurso. Ao apresentar os valores percentuais e as palavras em negrito, que conduzem o enunciatário a associar "Salesiano" a "Superior", o enunciador faz seu discurso parecer verdadeiro levando o enunciatário a crer nos valores postos, ou seja, que o Colégio Salesiano é uma boa escolha para quem deseja ser aprovado no vestibular. 


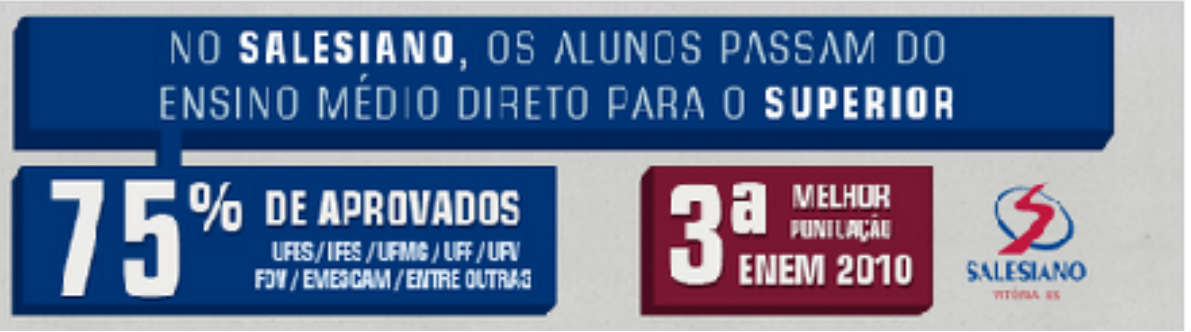

Imagem 13: Detalhe da página do site institucional do Colégio Salesiano Nossa Senhora da Vitória

Ao enunciar suas proposições pedagógicas, agendas, eventos culturais e acesso à rotina escolar dos alunos por seus pais e responsáveis, a escola cria um simulacro do espaço físico do Colégio Salesiano, sendo o site considerando então como o território propriamente dito. Em todos os links a escola destaca suas qualidades inteligíveis e seu papel social de educador, marcados por enunciados do fazer, fazendo com que o site se caracterize como espaço das regularidades. Os valores ali postos são todos da esfera do saber, e em alguns momentos da esfera do ser e do sentir, principalmente quando a escola destaca sua relação com a família, alunos e ex-alunos.

É claro que todas as categorias e relações acimas estabelecidas não são fixas. Sendo o ciberespaço um espaço estriado de práticas sociais complexas e vivenciados por sujeitos de identidade fragmentada, as relações estabelecidas são móveis, podendo ser alteradas de um dia para o outro.

A compreensão dos dois modos de apresentação da escola no ciberespaço possibilitou a estruturação do quadro abaixo que apresenta as categorias e suas oposições, nem sempre fixas, presentes na apresentação da escola na comunidade do Orkut e no site institucional:

\begin{tabular}{|l|l|l|}
\hline & NA COMUNIDADE & SITE INSTITUICIONAL \\
\hline Quanto à mobilidade & Móvel & Fixo \\
\hline Pessoa/espaço/tempo & Eu/ alhures/ então & Nós/ aqui/ agora \\
\hline Acesso & Público & Público / Privado \\
\hline Espaço & Reterritorialização & Território \\
\hline Quanto às experiências dos suje & Sensível & Inteligível \\
\hline Quanto aos regimes & $\begin{array}{l}\text { Ajustamento e } \\
\text { programação }\end{array}$ & $\begin{array}{l}\text { Manipulação e } \\
\text { programação }\end{array}$ \\
\hline
\end{tabular}




\begin{tabular}{|l|l|l|}
\hline Quanto à presença dos sujeitos & Pessoalidade & Impessoalidade \\
\hline Estado dos sujeitos & Subjetividade & Objetividade \\
\hline Quanto às programações & Irregularidades & Regularidades \\
\hline Quanto às Modalizações do ser & $\begin{array}{l}\text { Ser ser / fazer ser / } \\
\text { poder fazer }\end{array}$ & Dever fazer \\
\hline
\end{tabular}

\section{REFERÊNCIAS}

DAYTELL, Juarez. A escola como espaço sócio-cultural. In: DAYRELL, Juarez (Org.). Múltiplos olhares sobre educação e cultura. Belo Horizonte: UFMG, 1996.

DELEUZE, Gilles; GATTARI, Félix. Mil Platôs: Capitalismo e Esquizofrenia. Rio de Janeiro: Editora 34, 1996.

GREIMAS, A. J. COURTÉS, J. Dicionário de Semiótica. São Paulo: Contexto, 2008.

GREIMAS, Algirdas Julien. Da imperfeição. São Paulo: Hacker, 2002.

Semiótica e Ciências Sociais. São Paulo: Cultrix, 1976.

LANDOWSKI, Eric. Presenças do outro. São Paulo: Perspectiva, 2002.

Educ; Pontes, 1992.

A sociedade Refletida: ensaios de sociossemiótica. São Paulo:

Interacciones Arriesgadas. Peru: Universidad de Lima, 2009.

LEMOS, André. Aspectos da cibercultura - vida social nas redes telemáticas. In: Crítica das Práticas Midiáticas: da sociedade de massa às ciberculturas. São Paulo: Hacker, 2002.

Desterritorialização na Cibercultura. 2005. Disponível em: http://www.facom.ufba.br/ciberpesquisa/andrelemos/território.pdf. Acesso em: 18 jan. 2012.

SANTAELLA, Lucia; LEMOS, Renata. Redes Sociais Digitais: a cognição conectiva no twitter. São Paulo: Paulus, 2010.

TRIVINHO, Eugênio. A dromocracia cibercultural: lógica da vida humana na civilização mediática avançada. São Paulo: Paulus, 2007

O mal-estar da teoria: a condição da crítica na sociedade tecnológica atual. Rio de Janeiro: Quartet, 2001. 